\title{
Alfred Kinsey, Alone After an Interview, Dreams of Indiana - Michael Martone
}

for $L B B$

I COULD NEVER TELL a 'dirty' story. It is all in the telling, I'm convinced. There is the one about the new convict and the numbered jokes, but that is not the type of thing I am thinking about. Well, anyway, the new convict calls out a number, and no one laughs because some people can't tell a joke. The funny thing about that is a subject at San Quentin first tơid me that story. It still makes me laugh. Pomeroy laughed more out of respect than anything else. He was probably disappointed. I was, by that time, a kind of authority.

In the fall, Clara and I would borrow a car and head out of town on a Sunday. The leaves would be turning. I liked the way fall worked. The leaves not turning, really, only the green going and the carotene and the other dyes showing through for once.

It would never fail that on our way to Brown County another car would be pulled off on the shoulder. Its occupants would be picnicking or napping near an overlook. And with the leaves forgetting themselves all around us, so would we. We would strain to take a look at the parkers. All this nature, and it was our overwhelming nature to take a look at each other. I always used this anecdote to teach my beginning classes the concept of species recognition. Interbreeding population is the last distinction before variety. I am convinced. It is the only instinct. Our heads are literally turned.

Martin kept expecting the women to lift their blouses. He was always saddened by the disparity between the public story and the private history. He never doubted which one was true. I remember him going over the histories of his classmates at Indiana. With the files open before him, he just sat there shaking his head. He had believed everything his friends had told him.

The first warm day and the whole department would head out to the quarries around Bloomington. Imagine, in the first days of spring, their spouses within reach again, everyone is on the lookout for the return to life of some specific fauna. All these men, knowing the oestrus of their special species, have these females next to them on the crazy quilts. Our peculiar nature. Look at them. Their heads bent to the obscene buzz of zoölogy. The University spelled zoölogy with that pesky umlaut overhead. The mark of the Prussians left behind after drawing out the blood. There was a white dust on all the leaves from the gypsum factories. Spring in Indiana. The cut 
and tumbled blocks of the abandoned quarry would look like ruins to a German scholar. This was a new world for me. Let them find a story here. Clara was next to me, white from the winter but already tanning. The rocks were warming up. I had just turned associate, and I felt secure. So I stopped them before they could get their killing jars from the car by taking off my clothes and diving headlong into the pool of someone else's reflection.

We could talk shop in the most public places because of the code. In an elevator, we discussed a politician's incest or, in a busy lunch room, a woman's need for filthy language. I would say, "My last history liked Y better than $\mathrm{Cm}$ although Go in Cx made him very ez." That type of rendering made everyone more comfortable. That was during McCarthy and the Customs Case. Our books could not be sent through the mail. The Institute and the University were very sensitive. We had recently lost the Rockefeller money. No one was laughing at anything.

Clara and I, during the first hot summers in Bloomington, would walk its streets and alleys, mildly interested in the bees collecting around the backdoor rubbish bins of restaurants. Pleased when we distinguished characteristics readily. Family, order, class. The tiny mass of Latin, yellow and brown, lighted on the red bricks. Their abdomens pulsed and touched. The wasps scribbled on the surface of a pool of water. Genus, species, variety. We went to Dunn Meadow and turned the oak leaves over in our hands, recognizing the wasp by the disruption of the cells, the black gall on the dull side of the leaf. Rummaging through campus to where the Jordan River disappeared underground, we read the leaves until it was too dark to see the beauty marks, left, and grabbed a bench on Kirkwood. From there we watched the couples collect under the yellow lights of the Von Lee as they waited to buy their tickets, and saw them touch each other. As we watched them touch from across the street, we did not care who was watching us. Paying no attention to the miller in the light or the cricket in the dark, we rounded the corner to the Book Nook, empty and quiet between terms. The jerk behind the counter told us again where the speaks were that summer as he screwed his towel into the glasses while I sat down at the piano where Hoagy Carmichael had composed "Stardust" and played Chopin and Beethoven, without distinction. We closed the place, circled back to ours, and, without turning on the lights, stumbled by the sheets of insects under glass, the cotton and the chlorides, the spreading boards and pins, and, with nothing left to identify, fell in bed with the house as hot as it had been all day.

My secret was never to be surprised. I told my interviewers to assume that everyone had done everything. Anything that could be imagined is humanly possible. We had only to ascertain when and how many times. 
Clara would sometimes bring my lunch down to Jordan Hall when the Institute was just setting up house. "Honey," I said to her, "this building will one day house more pornography than the Vatican." We laughed. She always understood when I was joshing. We sat on the steps where Dellenbeck liked to take our picture and watched the young men across the way strip down to the waist and knock off for lunch. The WPA was building Sycamore and the Auditorium, and the CCC was adding a wall around the campus. Everything was done in the local limestone which would turn from pink to gray in winter. That summer those boys with their farmer's tans molted into men. Thomas Hart Benton used some of them in the murals he did for the Auditorium. I took his history when he was on campus. That afternoon we shared a lunch Clara brought, back in the woods where the river traced through the exposed bedrock. He wore overalls and talked about Missouri. Clara sat with her legs curled under her skirt. He stretched out his hand and touched her cheek saying, simply, "Bounty."

Pomeroy thought I derived some pleasure from keeping secrets. That was the psychologist in him talking. I never would reveal anything, of course, nor hold anything over anyone's head. It wasn't power but general truth that interested me.

I remember when Pomeroy broke my code on his own, found and read my history and Clara's and the children's. Of course, I was upset, but it pleased me even more that he was so willing to learn.

Her waist was gone. She was white in the moonlight. I remember, because the curtains were gone. Laundry. The baby was showing and had already moved. It was past the time we had agreed upon to do anything more. Her waist was gone, and she was a different creature. But it was summer, I remember, because I would stay up after she went to sleep and listen for insects. She had longings for cream puffs. I could keep nothing from spoiling. She could no longer move. There was no more surprise in consequence. The introduction of love is its own undoing.

I told my researchers that there were only three ways a subject could not be telling the truth. He could exaggerate, conceal, or remember incorrectly. Our methods took care of all three. The number and speed at which we asked our questions took care of most problems. No one could prepare a life, especially a sexual one, on the spur of the moment. The rest was in the follow-up to see if the same lie could be told twice.

I no longer ask myself certain questions. Donald died the same year of my first Biology. It was Mill, I believe, who began his autobiography with a reference to his father's book on India. Author and Father. At the Institute, 
we interviewed each other every year or so. I have gone through my sexual history over twenty times. I have always found I am accurate; my stories match from year to year. The repetition makes everything clearer in my mind. In others, this justifies our methodology. The story is to remain the same. I am not so sure in my own case. I have been over everything again and again, but no single night presents itself to me as the one on which Donald was conceived. Sexual Behavior in the Human Male took ten years to write, and I can still tell you the seed of that story. I even remember what the woman wore, the pearl at her throat. Perfection out of irritation. She was one of the students in the marriage course. In conference, she asked me how much passion she should expect from her fiancé. And I didn't know. I didn't know. Not then. Donald was only three when he died. Sexless in that way. My first son. Some passion spent long ago.

I told my interviewers that some subjects would make advances. I prepared them for this as best I could because I knew it would happen. I had instructed them to always remain impassive. Nothing cools sexual ardor more than impassivity. We did not want to lose the oral history, though. I reminded them that this behavior, too, fell into that range we would come to call normal.

There were about fifty different measurements taken on each specimen of gall wasp. And this was only morphology, not phylogeny, host relationships, geographic distribution, life cycles and history, or gall polymorphism. I no longer had the time for these myself, and I could not find a graduate student so inclined. I was caught up in the other work. By this time I had finished two books on the Cynips. That was enough of a contribution.

I remember watching Clara once as she measured the third segment of antennae. She would still work on the plates with water colors and go over the Leach line drawings after the children were in bed. She would use the colored pencils to write me notes. I told her the new study interested me more. No more pictures to draw. "Imagine," I said, "the illuminated manuscript of this. A different box of colors." I gave the rest of the specimens to Harvard and went to the field again, collecting.

After watching a man in a West Side bar in New York for days, I approached him and said, "I am Dr. Kinsey, from Indiana University, and I am making a study of sex behavior. Can I buy you a drink?” What could he say? The truth is so wild sometimes. He was a homosexual prostitute and was so pleased that I had been telling the truth that for years after that he encouraged his friends to be interviewed. I took everyone's history. To this day, I do not understand what impressed him more. My innocence or my knowledge. 
You know, I always hired interviewers with stable marriages. It was the nature of the work. My experience of Americans led me to believe that they are skeptical of those who cannot keep house and home together. Ironically, we had to travel a great deal; we really did, and then be alone with those consenting strangers in any little bit of privacy we could find. In our situation very little was lost on us.

Clara stayed behind with the children. I left with the men, and she finished the pictures she had started years before of the gold bands on the abdomen of Sphecids.

So many people wanted to tell me things. I let them. They believed I would never interpret their behavior right there in front of them. I simply let them talk. That was what was important. Let them hear themselves. I just listened. They wanted to tell me secrets so that someone knew they kept them, that they had something to keep. When the study started, I, of course, interviewed myself, following my life until its history ran out. I could not interpret it by itself. Clara's history, the one Pomeroy came across, was contrived from the things I knew. She could never tell me things. I made it all up.

There are many ways of saying "yes." I have trained myself to hear all of those distinctive inflections. When I interviewed, the code we used could represent every subtlety by making each different affirmation a different word like the Eskimo vocabulary for our word snow. There is even a "yes" that means "no," of course, and the many ways of saying no. This is all I have needed to understand all the lovers of the world.

Winter in Indiana. The brown oak leaves stay on the tree through the winter and fall the next spring. The dry leaves say "yes." The stones turn from pink to gray. I will die of this enlarged heart, my doctor says, because there is no time to take the rest I need. 